\title{
Analisis Pengaruh Orientasi Kewirausahaan, Inovasi dan Kapabilitas Pemasaran terhadap Keunggulan Bersaing pada UKM Olahan Ikan di Semarang
}

\author{
LISDARAHMASARI \\ Universitas Maritim AMNI \\ Jl. Soekarno-Hatta No.180 Semarang \\ Email : lisdarahmasari272@gmail.com
}

Diterima 1 Maret 2021; disetujui 15 Maret 2021;

\begin{abstract}
This study aimed to find out the influence of entrepreneurial orientation, innovation and marketing capabilities on competitive advantage. The research population comprised Fish Processing Business in Semarang City. The sample was selected by means of the purposive sampling technique. The sample was 100 companies. The data were collected by a questionnaire, interviews, and documentation. This research uses Structural Equation Modeling (SEM) analysis technique using AMOS 24.0 analysis tool. The test results using Structural Equation Modeling (SEM) analysis techniques indicate that the model is in accordance with population data. The results of the study showed that entrepreneurship oriented, innovation and marketing capabilities had a significant positive effect on competitive advantage. Used by analyzer for example validity test, test reliabilitas, and hipotesis test use modelling equation structural (SEM).
\end{abstract}

Keywords : Entrepreneurial Orientation, Innovation, Marketing Capabilities and Competitive Advantage

\section{PENDAHULUAN}

Keberadaan pemerintah dalam hal peningkatan kinerja usaha kecil dan menengah sudah sangat serius. Ini terbukti dari pemberian kredit lunak kepada pemilik usaha untuk dapat meningkatkan kapabilitas mereka dalam meningkatkan kinerja perusahaan, namun pemberian kredit oleh pemerintah masih kurang merata, karena banyaknya usaha kecil dan menengah yang ada di Indonesia. Kecenderungan pemberian kredit lebih banyak pada pengusaha besar dibandingkan pengusaha kecil dan menengah karena alasan kelemahan manajerial pemasaran. Sebagian UKM masih mempunyai berbagai kelemahan yang bersifat eksternal, seperti kurangnya kemampuan untuk beradaptasi terhadap pengaruh lingkungan yang strategis, kurang cepat dalam melihat peluang-peluang usaha, kurangnya kreativitas dan inovasi dalam mengantisipasi berbagai tantangan sebagai akibat resesi ekonomi yang berkepanjangan. Disamping 
itu faktor internal dari sebagian UKM yaitu kurangnya kemampuan manajerial dan keterampilan, kurangnya akses terhadap informasi teknologi, permodalan dan pasar. Kelemahan internal ini disebabkan sebagian SDM pengelola UKM kurang berkualitas dalam mengantisipasi berbagai masalah yang sedang dihadapi. Dari berbagai kekurangan yang tersebut diatas diperlukan adanya perhatian khusus terhadap nasib dari keberadaan UKM sebagai penunjang ekonomi riil masyarakat. Persaingan usaha yang begitu ketat mengharuskan perusahaan memiliki keunggulan bersaing, jika tidak maka perusahaan tersebut tidak dapat bertahan lama.

Di sisi lain, dunia bisnis kini mulai menganut pemikiran baru, dimana kewirausahaan disebut sebagai salah satu faktor untuk mewujudkan pertumbuhan ekonomi perusahaan berkelanjutan dan berdaya saing tinggi. Wirausaha sendiri berarti suatu kegiatan manusia dengan mengerahkan tenaga pikiran atau badan untuk menciptakan atau mencapai suatu pekerjaan yang dapat mewujudkan insan mulia. Orientasi kewirausahaan adalah kunci untuk meningkatkan kinerja pemasaran. Perusahaan yang pemimpinnya berorientasi pada wirausaha biasanya memilki visi yang jelas dan berani untuk menghadapi risiko sehingga mampu menciptakan kinerja yang baik.

Pelanggan umumnya menginginkan produk-produk yang inovatif sesuai dengan keinginan mereka. Bagi perusahaan, keberhasilannya dalam melakukan inovasi berarti perusahaan tersebut selangkah lebih maju dibandingkan pesaingnya. Hal ini menuntut kepandaian perusahaan dalam mengenali selera pelanggannya sehingga inovasi yang dilakukannya pada akhirnya memang sesuai dengan keinginan pelanggannya. Dengan demikian inovasi harus benar-benar direncanakan dan dilakukan dengan cermat. Per- usahaan secara potensial memiliki akses pada kapabilitas pemasaran yang berbeda. Kapa-bilitas dengan visi membangun posisi pasar sehingga dapat bertahan merupakan elemen kunci dalam kegiatan pemasaran perusahaan. Perusahaan bisa saja terlihat mempertahankan beberapa posisi dalam sebuah pasar, tapi yang paling populer adalah terkait dengan kemampuan untuk menjadi berbeda berdasarkan kualitas atau harga dari sebuah produk ataupun pelayanan (Porter, 2010). Inilah bentuk integrasi kapabilitas pemasaran dan konsep keunggulan bersaing. Kendala yang dihadapi oleh pengusaha kecil adalah kendala intern, yaitu kualitas SDM yang masih rendah, lemahnya peningkatan akses dan pengembangan pangsa pasar, lemahnya struktur pemodalan, terbatasnya kemampuan penguasaan teknologi, lemahnya organisasi dan manajemen, terbatasnya jaringan usaha dan kerjasama dengan pelaku-pelaku ekonomi lainnya. Yang kedua adalah kendala ekstern, yaitu akses sarana dan prasarana ekonomi yang belum memadai dan masih terpusat di pulau jawa, iklim usaha yang kurang kondusif karena masih banyaknya persaingan yang kurang sehat, serta pembinaan yang belum terpadu dari pemerintah. Dalam tahun-tahun mendatang industri kecil di kota Semarang nampaknya akan terus mengalami peningkatan yang ditunjang oleh beberapa faktor yaitu :

a. Merupakan pilihan potensial, karena hanya memerlukan modal yang kecil

b. Faktor keunggulan yang komparatif, karena hanya memerlukan tenaga kerja yang tidak perlu banyak.

c. Dalam proses produksinya dapat menggunakan teknologi yang sederhana.

d. Jumlah penduduk Indonesia yang cukup besar dan cukup konsumtif merupakan potensi pasar yang cukup besar pula sebagai pengguna produk. 
Pendatang baru semakin mudah masuk dari waktu ke waktu, dan perubahanperubahan berlangsung sedemikian cepat. Perusahaan yang kurang jeli akan menghadapi berbagai permasalahan, sehingga dengan alasan inilah diperlukan kreativitas manajemen dengan program-program pemasaran untuk dapat terus bertahan dalam dunia bisnis. Perubahan yang sedemikian cepat tanpa disadari telah mendorong banyak pihak (manajemen) untuk menghasilkan produk-produk baru yang bertujuan menarik minat pelanggan karena ada persaingan yang ketat di antara perusahaan. Pengembangan ide atau gagasan yang unik tentunya membutuhkan kompetensi dan kapabilitas dalam pemasaran, agar kinerja pemasaran dapat dihasilkan secara optimal. Oleh karena itu, penelitian ini akan mencoba membahas beberapa temuan dan implikasi penelitian terdahulu dan fenomena bisnis yang terjadi di usaha kecil menengah, di mana variabel orientasi kewirausahaan, inovasi, dan kapabilitas pemasaran menjadi faktor pendukung upaya-upaya perusahaan mencapai keunggulan bersaing yang berkelanjutan.

\section{TINJAUAN TEORITIS}

Keunggulan Bersaing. Perusahaan yang terus memperhatikan perkembangan kinerjanya dan berupaya untuk meningkatkan kinerja tersebut memilki peluang mencapai posisi persaingan yang baik maka sebenarnya perusahaan telah memilki modal yang kuat untuk terus bersaing dengan perusahan lain. Bharadwaj et al.,( 2011 ) menjelaskan bahwa keunggulan bersaing merupakan hasil dari implementasi strategi yang memanfaatkan berbagai sumberdaya yang dimiliki perusahaan. Keahlian dan asset yang unik dipandang sebagai sumber dari keunggulan bersaing. Keahlian unik merupakan kemampuan perusahaan untuk menjadikan para karyawannya sebagai bagian penting dalam mencapai keunggulan bersaing. Kemampuan perusahaan dalam mengembangkan keahlian para karyawannya dengan baik akan menjadikan perusahaan tersebut unggul dan penerapan strategi yang berbasis sumber daya manusia akan sulit untuk ditiru oleh para pesaingnya. Sedang asset atau sumber daya unik merupakan sumber daya nyata yang diperlukan perusahaan guna menjalankan strategi bersaingnya. Kedua sumber daya ini harus diarahkan guna mendukung penciptaan kinerja perusahaan yang berbiaya rendah dan memilki perbedaan dengan perusahaan lain. Pendapat yang serupa juga dikemukakan oleh Porter (2010) yang menjelaskan bahwa keunggulan bersaing adalah jantung kinerja pemasaran untuk menghadapi persaingan. Keunggulan bersaing diartikan sebagai strategi benefit dari perusahaan yang melakukan kerjasama untuk menciptakan keunggulan bersaing yang lebih efektif dalam pasarnya. Strategi ini harus didesain untuk mewujudkan keunggulan bersaing yang terus menerus sehingga perusahaan dapat mendominasi baik dipasar maupun pasar baru.

Keunggulan bersaing pada dasarnya tumbuh dari nilai-nilai atau manfaat yang diciptakan oleh perusahaan bagai para pembelinya. Pelanggan umumnya lebih memilih membeli produk yang memiliki nilai lebih dari yang diinginkan atau diharapkannya. Namun demikian nilai tersebut juga akan dibandingkan dengan harga yang ditawarkan. Pembelian produk akan terjadi jika pelanggan menganggap harga produk sesuai dengan nilai yang ditawarkannya. Beberapa indikator yang digunakan untuk mengukur keunggulan bersaing adalah keunikan, jarang dijumpai, tidak mudah ditiru, tidak 
mudah diganti, dan harga bersaing. Keunikan produk adalah keunikan produk perusahaan yang memadukan nilai seni dengan selera pelanggan. Harga bersaing adalah kemampuan perusahaan untuk menyesuaikan harga produknya dengan harga umum di pasaran.Tidak mudah dijumpai berarti keberadaannya langka dalam persaingan yang saat ini dilakukan. Tidak mudah ditiru berarti dapat ditiru dengan tidak sempurna. Sulit digantikan berarti tidak memiliki pengganti yang sama.

Orientasi Kewirausahaan. Kewirausahaan dikenal sebagai pendekatan baru dalam pembaruan kinerja perusahaan. Hal ini, tentu harus direspon secara positif oleh perusahaan yang mulai mencoba bangkit dari keterpurukan ekonomi akibat krisis berkepanjangan. Kewirausahaan disebutsebut sebagai spearhead (pelopor) untuk mewujudkan pertumbuhan ekonomi perusahaan berkelanjutan dan berdaya saing tinggi. Membangun kewirausahaan dinyatakan sebagai satu dari empat pilar dalam memperkuat lapangan pekerjaan. Sedangkan wirausaha sendiri berarti suatu kegiatan manusia dengan mengerahkan tenaga pikiran atau badan untuk mencapai/menciptakan suatu pekerjaan yang dapat mewujudkan insan mulia. Dengan kata lain, wirausaha berarti manusia utama (unggul) dalam menghasilkan suatu pekerjaan bagi dirinya sendiri atau orang lain. Orang yang melakukan wirausaha dinamakan wirausahawan. Kemampuan berinovasi adalah titik penting dari kewirausahaan dan esensi dari karakteristik kewirausahaan. Proaktifitas seseorang untuk berusaha berprestasi merupakan petunjuk lain dari aplikasi atas orientasi kewirausahaan secara pribadi. Demikian pula bila suatu perusahaan menekankan proaktifitas dalam kegiatan bisnisnya, maka perusahaan tersebut telah melakukan aktifitas kewirausahaan yang akan secara otomatis men- dorong tinginya kinerja (Weerawardena, 2003). Perusahaan dengan aktifitas kewirausahaan yang tinggi berarti tampak dari tingginya semangat yang tidak pernah padam karena hambatan, rintangan, dan tantangan. Sikap aktif dan dinamis adalah kata kuncinya. Seseorang yang berani mengambil risiko dapat didefinisikan sebagai seseorang yang berorientasi pada peluang dalam ketidakpastian konteks pengambilan keputusan. Hambatan risiko merupakan faktor kunci yang membedakan perusahaan dengan jiwa wirausaha dan tidak. Fungsi utama dari tingginya orientasi kewirausahaan adalah bagaimana melibatkan pengukuran risiko dan pengambilan risiko secara optimal. Penelitian ini mengadopsi indikator variabel orientasi kewirausahaan, yaitu: kemampuan berinovasi, proaktitas, dan keberanian dalam mengambil risiko seperti yang telah digunakan dalam penelitian Weerawardena (2003).

Inovasi. Inovasi merupakan sesuatu yang dapat dilihat sebagai kemajuan fungsional yang dapat membawanya selangkah lebih maju dibandingkan pesaing, apabila memiliki suatu kelebihan yang dipandang sebagai nilai tambah bagi konsumen. Pengembangan produk baru dan strateginya yang lebih efektif seringkali, menjadi penentu keberhasilan dan kelangsungan hidup suatu perusahaan, tetapi ini bukanlah sebuah pekerjaan yang mudah. Pengembangan produk baru memerlukan upaya, waktu dan kemampuan termasuk besarnya risiko dan biaya kegagalan. Cooper (2000) menjelaskan bahwa keunggulan produk baru sangat penting dalam lingkaran pasar global yang sangat bersaing. Keunggulan tersebut tidak lepas dari pengembangan produk inovasi yang dihasilkan, sehingga akan mempunyai keunggulan dipasar yang selanjutnya akan menang dalam persaingan. Wahyono(2002) menjelaskan bahwa inovasi 
yang berkelanjutan dalam suatu perusahaan merupakan kebutuhan dasar yang pada gilirannya akan mengarah pada terciptanya keunggulan kompetitif. Secara konvensional, istilah inovasi dapat diartikan sebagai terobosan yang berkaitan dengan produkproduk baru. Namun seiring dengan perkembangan yang terjadi, pengertian inovasi juga mencakup penerapan gagasan atau proses baru. Inovasi juga dipandang sebagai mekanisme perusahaan dalam beradaptasi dengan lingkungannya yang dinamis. Perubahan-perubahan yang terjadi dalam lingkungan bisnis telah memaksa perusahaan untuk mampu menciptakan pemikiran-pemikiran baru, gagasan-gagasan baru, dan menawarakan produk inovatif. Dengan demikian inovasi semakin memiliki arti penting bukan saja sebagai suatu alat untuk mempertahankan kelangsungan hidup perusahaan melainkan juga untuk unggul dalam persaingan.

Beberapa indikator yang digunakan untuk menilai inovasi adalah daya kreatifitas, inovasi teknis, perubahan desain, perubahan sistem distribusi, dan sistem administrasi pembayaran. Inovasi teknis adalah inovasi pada proses perusahaan dalam menghasilkan produk. Perubahan desain adalah kemampuan perusahaan untuk menghasilkan produk sesuai keinginan pelanggan. Daya kreatifitas adalah kemampuan perusahaan untuk menciptakan atau mengembangkan ide-ide baru. Perubahan sistem distribusi adalah upaya perusahaan untuk mengembangkan sarana distibusi yang tepat.

Kapabilitas Pemasaran. Kapabilitas pemasaran memungkinkan bisnis memberikan nilai tambah dan menciptakan nilai bagi pelanggan serta menjadi kompetitif. Sudut pandang berdasar sumber daya dari perusahaan menganjurkan hasil yang diharapkan dari usaha manajemen perusahaan merupakan penciptaan danpengiriman dari keunggulan kompetitif yang berkelanjutan yang pada akhirnya adalah pencapaian kinerja bisnis yang unggul. Menurut sudut pandang berbasis sumber daya, keunggulan kompetitif dapat dicapai melalui kepemilikan asset penting atau kapabilitas. Kapabilitas untuk mengadopsi batas strategis dioperasionalisasikan dengan menggunakan 3 (tiga) konstruk yaitu apakah tujuan utama organisasi adalah untuk bertahan; memperoleh keuntungan jangka pendek; atau membangun posisi pasar dalam jangka panjang. Pada akhirnya kapabilitas dalam membangun posisi pasar agar dapat bertahan dilihat sebagai elemen kunci dalam kegiatan pemasaran perusahaan (Porter, 2010). Perusahaan boleh saja terlihat mempertahankan beberapa posisi dalam sebuah pasar, tapi yang paling populer adalah terkait dengan kemampuan untuk menjadi berbeda berdasarkan kualitas atau harga dari sebuah produk ataupun pelayanan (Porter, 2010). Ada tiga posisi yang seharusnya diperoleh, yaitu kualitas produk yang lebih baik dibandingkan dengan pesaing; kualitas layanan yang lebih baik dibandingkan dengan pesaing; kualitas harga yang lebih kompetitif dibandingkan dengan pesaing (Porter, 2010). Karena kapabilitas pemasaran merupakan konsep penilaian atas kinerja proses dalam pemasaran, maka penelitian ini mengadopsi dimensionalisasi variabel kapabilitas pemasaran yang meng-ukur variabel ini dengan pendekatan bauran pemasaran, yakni jaringan distribusi, riset pemasaran dan pengembangan produk, strategi harga, dan manajemen promosi.

Hipotesis. Berdasarkan telaah pustaka dan model pemikiran teoritis, maka hipotesis yang diajukan dalam penelitian ini adalah :

H1 : Orientasi kewirausahaan berpengaruh positif terhadap daya saing produk 
$\mathrm{H} 2$ : Inovasi berpengaruh positif terhadap daya saing produk.

H3 : Kapabilitas Pemasaran berpengaruh positif terhadap daya saing produk

Indikator variabel orientasi kewirausahaan. Orientasi wirausaha adalah kemampuan kreatif dan inovatif yang dijadikan dasar, dan sumber daya untuk mencari peluang menuju kesuksesan. Ada tiga indikator untuk mengukur orientasi kewirausahaan dalam penelitian ini :

- Mengambil risiko dapat didefinisikan sebagai seseorang yang berorientasi pada peluang dalam ketidakpastian konteks pengambilan keputusan (x1)

- Flexibel adalah dapat berubah sesuai dengan keinginan pelanggan (x2).

- Antisipatif adalah kemampuan perusahaan dalam menanggulangi atau mengantisipasi terhadap segala perubahan (x3).

Indikator variabel Inovasi. Inovasi adalah konsep yang lebih luas yang membahas penerapan gagasan,produk atau proses yang baru. Ada tiga indikator untuk mengukur inovasi dalam penelitian ini, yaitu :

- Inovasi teknis adalah inovasi pada proses perusahaan dalam menghasilkan produk (x4).

- Perubahan desain adalah kemampuan per-usahaan untuk menghasilkan produk sesuai keinginan pelanggan (x5).

- Daya kreatifitas adalah kemampuan perusahaan untuk menciptakan atau mengembangkan ide-ide baru (x6).

Kapabilitas Pemasaran. Ada tiga indikator kapabilitas pemasaran (Tsai \& Shih, 2004) antara lain :

- Tingkat kemampuan dalam mengelola jaringan distribusi secara kualitatif (x7).

- Tingkat kemampuan dalam mengelola riset pemasaran dan pengembangan produk secara kualitatif (x8).

- Tingkat kemampuan dalam mengelola strategi harga secara kualitatif (x9).
Indikator variabel keunggulan bersaing. Keunggulan bersaing diartikan sebagai strategi benefit dari perusahaan yang melakukan kerjasama untuk menciptakan keunggulan bersaing yang lebih efektif dalam pasarnya. Ada tiga indikator yang digunakan untuk mengukur keunggulan besaing dalam penelitian ini, yaitu :

- Keunikan produk adalah keunikan produk perusahaan yang memadukan nilai seni dengan selera pelanggan (x10).

- Harga bersaing adalah kemampuan perusahaan untuk menyesuaikan harga produknya dengan harga umum di pasaran (x11).

- Jarang dijumpai berarti keberadaanya langka dalam persaingan yang saat ini dilakukan (x12).

\section{METODE PENELITIAN}

Populasi dan Sampel. Batasan industri kecil, menurut Badan Pusat Statistik :

- Jumlah tenaga kerja 5 sampai dengan 19 orang

- Kekayaan bersih termasuk tanah dan bangunan tempat usaha kurang atau sama dengan 200 juta ( $\leq 200$ juta )

Batasan industri menegah, menurut Badan Pusat Statistik:

- Jumlah tenaga kerja 20 sampai dengan 99 orang.

- Kekayaan bersih termasuk tanah dan bangunan tempat usaha lebih dari 200 juta tapi tidak lebih dari atau sama dengan 10 milyar ( 200 juta <kekayaan $\leq$ 10 milyar ). Populasi penelitian adalah UKM manufak-tur di Kota Semarang adalah 100 unit

Responden utama kuesioner ini adalah pemilik atau manajer, karena keberhasilan suatu perusahaan sangat dipengaruhi oleh peran serta para pemilik/manajer itu sendiri. Karena penelitian ini menggunakan metode 
sensus, maka responden adalah 100 UKM Olahan Ikan yang terdapat di Kota Semarang.

Teknik Analisis. Penelitian ini membutuhkan suatu analisis data dan intepretasinya yang akan digunakan untuk menjawab pertanyaan-pertanyaan penelitian untuk mengungkap fenomena sosial tertentu. Sehingga analisa data adalah proses penyederhanaan data ke dalam bentuk yang lebih mudah dibaca dan diinterpretasikan. Model yang akan digunakan dalam penelitian ini adalah model kausalitas atau hubungan atau pengaruh dan untuk menguji hipotesis yang diajukan, maka teknik analisis yang digunakan adalah SEM (Structural Equation Modelling) dari pakar statistic AMOS. Alasan penggunaan SEM (Struc-tural Equation Modelling) adalah karena teknik multivariat ini yang menggabungkan aspek dari regresi berganda (meneliti hubungan ketergantungan) dan analisis faktor untuk mengestimasi rangkaian hubungan ketergantungan yang saling ber-hubungan secara simultan (Hair et al.,1999).

\section{HASIL DAN PEMBAHASAN}

Analisis Structural Equation Model. Analisis selanjutnya adalah analisis Structural Equation Model (SEM) secara Full Model yang dimaksudkan untuk menguji model dan hipotesis yang dikembangkan dalam penelitian ini. Pengujian model dalam Structural Equation Model dilakukan dengan dua pengujian, yaitu uji kesesuaian model dan uji signifikansi kausalitas melalui uji koefisien regresi.

Berdasarkan hasil pengamatan pada gambar pada grafik analisis full model dapat ditunjukkanbahwa model memenuhi kriteria fit, hal ini ditandai dengan nilai dari hasil perhitungan memenuhikriteria layak full model.

\section{Gambar 1}

\section{Hasil Uji Structural Equation Model}

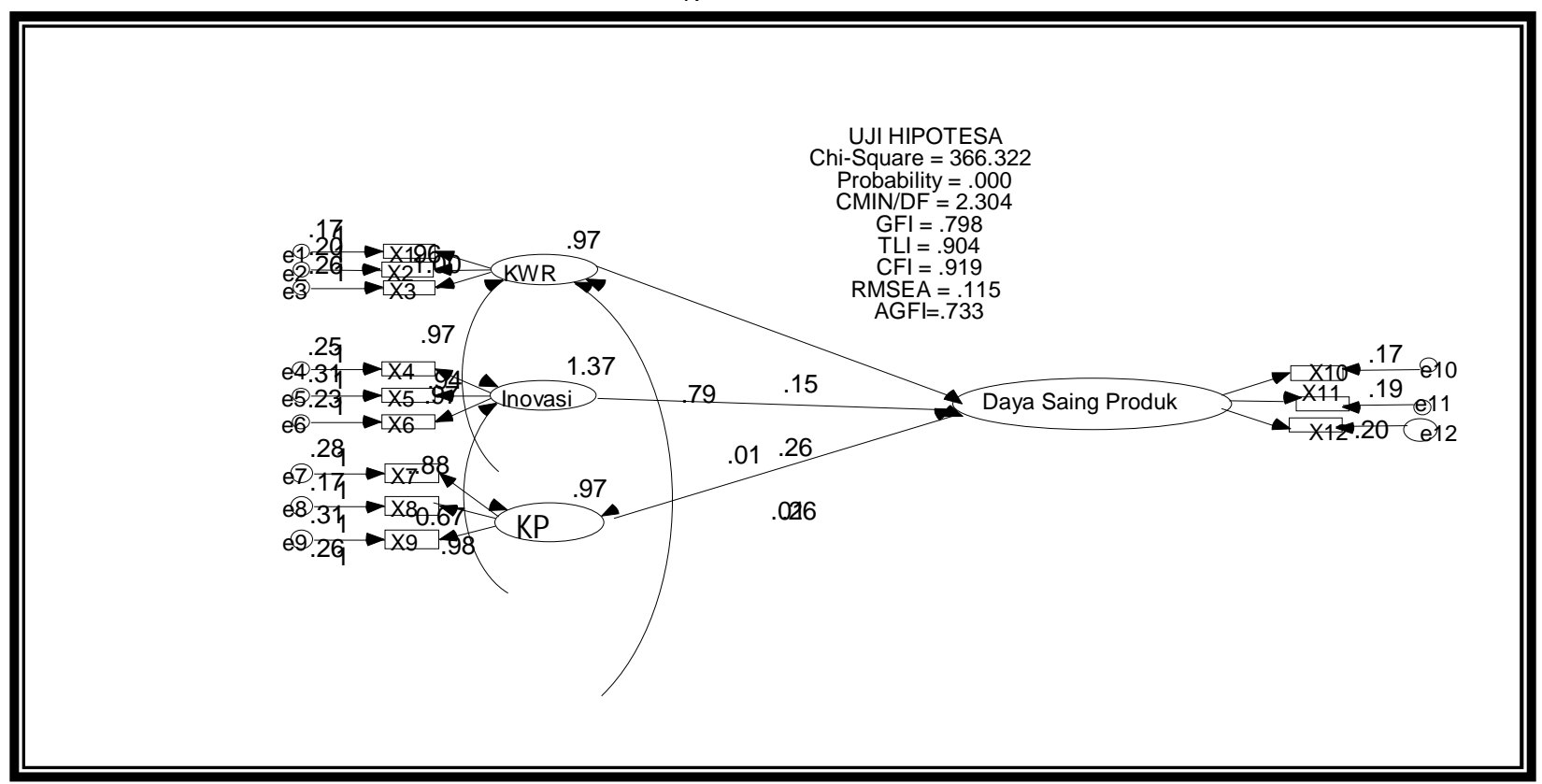

Sumber : Data amos yang diolah, 2021 
Tabel 1

Evaluasi Kinerja Goodness of Fit

\begin{tabular}{lccc}
\hline \multicolumn{1}{c}{ Kriteria } & Hasil Model & $\begin{array}{c}\text { Nilai Kritis } \\
\text { (Cut off Model })\end{array}$ & Evaluasi Model \\
\hline Chi Square & 60.322 & Kecil & Cukup Baik \\
Probability & 0.324 & $>0.05$ & Baik \\
Cmin/df & 1.304 & $\leq 2.0$ & Baik \\
GFI & 0.908 & $\geq 0.90$ & Baik \\
TLI & 0.964 & $\geq 0.95$ & Baik \\
CFI & 0.959 & $\geq 0.95$ & Baik \\
RMSEA & 0.075 & $\leq 0.08$ & Baik \\
AGFI & 0.933 & $\geq 0.90$ & Baik \\
\hline
\end{tabular}

Sumber : Data primer yang diolah dengan AMOS

Tabel 2

Regression Weight

\begin{tabular}{lllll}
\hline & & & C.R. & P \\
\hline Daya Saing & $<---$ & Kewirausahaan & 2.3 & .0 \\
Daya Saing & $<---$ & Inovasi & 2.3 & .0 \\
Daya Saing & $<---$ & Kapabilitas Pemasaran & 2.1 & .0 \\
X3 & $<---$ & Kewirausahaan & 12.3 & .0 \\
X2 & $<---$ & Kewirausahaan & 14.3 & .0 \\
X1 & $<---$ & Kewirausahaan & 14.9 & .0 \\
X4 & $<---$ & Inovasi & 14.3 & .0 \\
X5 & $<---$ & Inovasi & 14.5 & .0 \\
X6 & $<---$ & Inovasi & 16.0 & .0 \\
X7 & $<---$ & Kapabilitas Pemasaran & 14.2 & .0 \\
X8 & $<---$ & Kapabilitas Pemasaran & 14.5 & .0 \\
X9 & $<---$ & Kapabilitas Pemasaran & 12.4 & .0 \\
X12 & $<---$ & Daya Saing & 11.9 & .0 \\
X11 & $<---$ & Daya Saing & 11.6 & .0 \\
X10 & $<---$ & Daya Saing & 12.8 & .0 \\
\hline
\end{tabular}

Sumber : Data primer yang diolah dengan AMOS

Berdasarkan pada gambar 1 dan tabel 1 bahwa setiap indikator pembentuk variabel latenmenunjukkan hasil yang memenuhi kriteria yaitu nilai $\mathrm{CR}$ di atas 1,96 dengan $\mathrm{P}$ lebih kecil dari pada 0,05 dan nilai lambda atau loading factor yang lebih besar dari 0,5.
Hasil tersebut dapat dikatakan bahwa indikator-indikator pembentuk variabel laten tersebut secara signifikan merupakan indikator dari faktor-faktor laten yang dibentuk. Dengan demikian, model yang dipakai dalam penelitian inidapat diterima. 
Uji Hipotesis Pengaruh Orientasi Kewirausahaan Terhadap Daya Saing Produk. Hipotesis 1 pada penelitian ini orientasi kewirausahaan mempunyai pengaruh positif terhadap daya saing produk, yang artinya semakin tinggi orientasi pasar, maka semakin tinggi daya saing produk. Berdasarkan hasil dari pengolahan data diketahui bahwa nilai Critical Ratio (CR) pengaruh antara variabel orientasi kewirausahaan terhadap daya saing produk adalah sebesar 2.3 dengan nilai probability $(\mathrm{P})$ sebesar 0.000 . Hasil dari kedua nilai ini memberikan informasi bahwa pengaruh variabel orientasi kewirausahaan terhadap daya saing produk dapat diterima, karena memenuhi syarat di atas 1,96 untuk Critical Ratio (CR) dan dibawah 0.05 untuk nilai probability $(\mathrm{P})$, dengan demikian dapat dikatakan bahwa hipotesis 1 penelitian ini dapat diterima.

\section{Uji Hipotesis Pengaruh Inovasi} Terhadap Daya Saing Produk. Hipotesis 2 pada penelitian ini inovasi mempunyai pengaruh positif terhadap daya saing produk, yang artinya semakin tinggi inovasi, maka semakin tinggi daya saing produk. Berdasarkan hasil dari pengolahan data diketahui bahwa nilai Critical Ratio (CR) pengaruh antara variabel inovasi terhadap daya saing produk adalah sebesar 2,3 dengan nilai Probability (P) sebesar 00. Hasil dari kedua nilai ini memberikan informasi bahwa pengaruh variabel inovasi terhadap daya saing produk dapat diterima, karena memenuhi syarat di atas 1,96 untuk Critical Ratio (CR) dan dibawah0.05 untuk nilai probability $(\mathrm{P})$, dengan demikian dapat dikatakan bahwa hipotesis 2 penelitian ini dapat diterima.

Uji Hipotesis Pengaruh Kapabilitas Pemasaran Terhadap Daya Saing Produk. Hipotesis 3 pada penelitian ini kapabilitas pemasaran mempunyai pengaruh positif terhadap daya saing produk, yang artinya semakin tinggi kapabilitas pemasaran, maka semakin tinggi daya saing produk. Berdasarkan hasil dari pengolahan data diketahui bahwa nilai Critical Ratio (CR) pengaruh antara variabel kapabilitas pemasaran terhadap daya saing produk adalah sebesar 2,431 dengan nilai Probability (P) sebesar 0.0 Hasil dari kedua nilai ini memberikan informasi bahwa pengaruh variabel kapabilitas pemasaran terhadap daya saing produk dapat diterima, karena memenuhi syarat di atas 1,96 untuk Critical Ratio (CR) dan dibawah 0.05 untuk nilai probability $(\mathrm{P})$, dengan demikian dapat dikatakan bahwa hipotesis 3 penelitian ini dapat diterima

\section{SIMPULAN}

1. Orientasi Kewirausahaan berpengaruh positif terhadap daya saing produk. Pengujian hipotesis yang dilakukan membuktikan bahwa ada pengaruh positif yang signifikan antara orientasi kewirausahaan dengan daya saing produk. Hal ini menunjukkan bahwa kemampuan pimpinan dalam mengelola perusahaan ternyata memberikan dampak pada kemampuan perusahaan untuk bersaing dengan perusahaan lain.

2. Inovasi berpengaruh positif terhadap daya saing produk. Pengujian hipotesis yang dilakukan membuktikan bahwa ada pengaruh positif yang signifikan antara inovasi dengan daya saing produk. Hal ini menunjukkan bahwa kemauan perusahaan untuk mengembangkan inovasi produknya ternyata memberikan dampak pada peningkatan kemampuan perusahaan dalam menghadapi persaingan.

3. Kapabilitas pemasaran berpengaruh positif terhadap daya saing produk. Hal ini menunjukkan bahwa kemampuan dan 
pengetahuan pemasaran ternyata memberikan dampak pada peningkatan kemampuan perusahaan dalam menghadapi persaingan.

\section{DAFTAR PUSTAKA}

Bharadwaj, Sundar G, P.R.Varadarajan, \& Fahly, Jihn. (2011). "Sustainable Competitive Advantage in Service Industries: A Conceptual Model and Research Propositions". Journal of Marketing. Vol.57, Oktober,p.83-99.

Burden, Rebecca \& Proctor, Tony. (2000). "Creating Sustainable Competitive Advantage Through Training". Team Performance Management AnInternational Journal. p.90-96.

Cooper, Robert G. (2000). "Product Inovation and Technology Strategy". Journal Research Technology Management.p.3841.

Droge, Cornelia \& Shownee Vickrey. (1994). “ Source and Outcomes of Competitive Advantage: An Explanory Study in The Furniture Industry". DecisionSciences.p.669-689.

Ferdinand, Augusty. (2000). "Manajemen Pemasaran: Sebuah Pendekatan Strategy". Research Paper Series. No.01 Program Magister Manajemen Universitas Diponegoro.

Ferdinand, Augusty. (2005). "Structural Equation Modelling Dalam Penelitian Manajemen". Seri Pustaka Kunci No.06 Program Magister Manajemen Universitas Diponegoro.

Hair, J.F., Anderson, R.E., Black, W.C. (1995). Multivariate Data Analysis With Reading. Fourth edition. Prentice Hall International.
Hamel, Gary \& CK Prahalad. (1991). "Competing For The Future". Boston: Harvard Business School Press.

Han, Jin K, Narwoon Kim \& Srivastava, Rajendra K. (1998). "Market Orientation an Organization Performance: Is Innovation Missing Link?".Journal ofMarketing.p.4254.

Indriantoro, Nur \& Supomo.(1999). Metodelogi Penelitian Bisnis untuk Akuntansi dan Manajemen. BPFE.Yogyakarta.

Kohli, A.K., \& Jaworski, B.J. (1990). "Market Orientation: The Construct, Researchroposition, and Managerial Implication". Journal of Marketing.p.1-18.

Kottler, Philip. (1997). Marketing Management. Edisi 8.Prentice Hall International.

Li, Tiger \& Roger J. Calantone. (1998). "The Impact of Market KnowledgeCompetence on New Product Advantage: Conceptualization and EmpiricalExam". Journal of Marketing. Vol.62,Oktober,p.1329.

Morris, H.Michael, Pamela S Lewis.(1995). "The Determinants of Entrepreneurial Activity, Implication for Marketing". European Journal of Marketing. Vol.29, No.7.

Narver, J.C., \& Slater, S.F. (1990).“The Effect of Market Orietation on Product Innovation". Journal of Marketing.p.20-35.

Porter, Michael, E. (2010). "Competitive Strategy". The Free Press. New York,p.20.

Weerawardena, Jay. (2003). "Exploring The Role of Market Learning Capability in Competitive Strategy". European Journal of Marketing. Vol.37,p.407-429.

Widiyanto, Ibnu. (2008). Pointers Metodologi Penelitian. Program Magister Manajemen Universitas Diponegoro. 